\title{
DEPDC1 wt Allele
}

National Cancer Institute

\section{Source}

National Cancer Institute. DEPDC1 wt Allele. NCI Thesaurus. Code C126130.

Human DEPDC1 wild-type allele is located in the vicinity of 1 p31.2 and is approximately 23 $\mathrm{kb}$ in length. This allele, which encodes DEP domain-containing protein $1 \mathrm{~A}$, plays a role in transcriptional regulation. Aberrant expression of this gene is associated with bladder cancer. 